\title{
Influence of calcined clay pozzolana on strength characteristics of Portland cement concrete
}

\author{
Eric Opoku Amankwah ${ }^{1}$, Mark Bediako², C. K. Kankam ${ }^{3}$ \\ ${ }^{1}$ Develoment Office, University of Education, Winneba, Kumasi Campus, Ghana \\ ${ }^{2}$ CSIR -Building and Road Research Institute, Kumasi, Ghana \\ ${ }^{3}$ Civil Engineering Department, Kwame Nkrumah University of Science and Technology, Kumasi, Ghana
}

Email address:

b23mark@yahoo.com (M. Bediako)

\section{To cite this article:}

Eric Opoku Amankwah, Mark Bediako, C. K. Kankam. Influence of Calcined Clay Pozzolana on Strength Characteristics of Portland Cement Concrete. International Journal of Materials Science and Applications. Vol. 3, No. 3, 2014, pp. 410-419.

doi: 10.11648/j.ijmsa.20140306.30

\begin{abstract}
The paper presents results of a study on concrete mixes containing two types of calcined clay pozzolanas obtained from Mankranso and Tanoso for structural application. Mankranso sample is labeled Type I whilst Tanoso also labeled as type II.Both clay samples were analysed to determine their physical and geotechnical properties whilst the chemical composition of the calcined clay samples analysed. Portland cement was replaced with 0\%-25\% Type I and 0-30\% of Type II pozzolanas to formulate binder pastes and concretes. Setting times and normal consistency test were determined on the formulated binder paste. Three grades of concrete $\left(25 \mathrm{~N} / \mathrm{mm}^{2}, 30 \mathrm{~N} / \mathrm{mm}^{2}\right.$ and $\left.40 \mathrm{~N} / \mathrm{mm}^{2}\right)$ containing pozzolana were prepared and their workability, density, compressive strength and flexural strength investigated against the plain concrete. Concretes with clay pozzolana had delayed setting times and lower densities. They also exhibited a reduction in compressive and tensile strength development at early age (7 days), with an average drop of 6 percent in compressive strength for all grades. However, the compressive and tensile strengths beyond 28 days notably exceeded the control un-blended mixes. This study recommends up to $20 \%$ clay pozzolana content of both Types I and II for concrete grades of $25 \mathrm{~N} / \mathrm{mm}^{2}, 30 \mathrm{~N} / \mathrm{mm}^{2}$ and $40 \mathrm{~N} / \mathrm{mm}^{2}$.
\end{abstract}

Keywords: Concrete, Calcined Clay, Normal Consistency, Concrete Grade, Compressive Strength, Flexural Strength, Setting Times, Workability

\section{Introduction}

Concrete is one of the most commonly used construction materials which largely affect the overall cost of buildings and civil engineering structures. It plays a key role in national development of all countries around the world. Globally concrete is only second to water as the most consumed substance with an annual estimated consumption of over 6 billion cubic metres [1]. Mehta and Monteiro [2] have projected that by 2050 approximately 18 billion tons of concrete would be demanded for construction worldwide. The huge demand for concrete translates to enormous environmental problems and economic issues. The environmental concerns are that damages are caused to arable lands through the extraction of raw materials (aggregates, limestone and clay). Coupled with this is carbon dioxide emission, a greenhouse gas emitted from cement industries which support the concrete industry. It is reported that the world's annual greenhouse gasses emission from cement industries is estimated to be 1.35 billion tonnes, corresponding to approximately $7 \%$ of the total greenhouse gasses [3]. Pursuit to this goal, about 1.6 billion metric tonnes of modified Portland cement is produced annually in the world [4].

Among modified cements utilized extensively is the incorporation of pozzolanas such as metakaolin, fly ash, silica fume, slag and bagasse ash. These pozzolanic admixtures are rich in silica and aluminas have positive effects on the properties of Portland cement concrete and mortar. With their inclusion in cement, they reduce cost of cement, increased compressive and tensile strength at later ages, improved workability, delayed setting times, reduced permeability, reduced thermal cracking and increased resistance to sulphate and chloride attacks.

Alam et al [5] investigated into the mechanical, durability and economic values of pozzolanic fly ash in concrete. They found that between 5 and $10 \%$ of cement replacement by fly ash had no negative effect on strength and durability of concrete. The priceless nature of fly ash therefore reduced 
cement cost. The studies of $\mathrm{Vu}$ et al [6] and Sumrerang and Prinya [12] used calcined kaolin and bagasse ash at $20 \%$ and $30 \%$ optimum values respectively to replace cement. Their results showed an enhanced strength characteristics than the control cement mix. Pozzolans delay setting times and this was shown in the studies of Vu et al [6] and Fragoulis et al [8]. Other characteristics such as reduced permeability and increased resistance to sulphate and chloride with the utilization of pozzolanic materials have been shown in the studies of Al-Dulaijan [9], Shehata et al [10] and Thomas et al [11], Sumrerng and Prinya [12] respectively.

The possibility of using clay as a pozzolanic material has been investigated previously by Tironi et al. [13] and Sabir et al. [14]. Other studies conducted in Ghana have shown that blending up to $25 \%$ of Mankranso or $30 \%$ of Tanoso with Portland cement produced strength classes that met the minimum strength requirement of $42.5 \mathrm{~N} / \mathrm{mm}^{2}$ [15]. It has been shown that clay deposits exist throughout Ghana estimated at 1.39 billion metric tonnes [16]. This study therefore present the outcome of the investigations performed on some properties of concrete using clay pozzolana as cement mineral admixture for structural purposes. Some of the properties investigated include consistency, setting times, workability, density, compressive and tensile strength.

\section{Materials and Experimental Program}

\subsection{Materials}

Two clay deposits located at Mankranso in the Ashanti region and Tanoso in the Brong Ahafo region were selected. The samples of clay pozzolana obtained from Mankranso and Tanoso clays were labeled as Type I and Type II. The physical and geotechnical properties of raw clay samples are were shown in Table 1. Table 2 also gives the chemical composition of the pozzolana produced from Type I and Type II clay samples as well as the cement. The X-ray fluorescence instrument was used to analyze the various chemical compositions. From Table 2, the pozzolana samples could be classified as a Class $\mathrm{N}$ pozzolana according to the ASTM: C618. The LOI values obtained for Type I and Type II pozzolana were 9.00 and 8.00 respectively, lower than the $10 \%$ required according to ASTM C618.Ordinary Portland cement conforming to ASTM: C150 of strength class $42.5 \mathrm{~N}$ were used to prepare the Portland pozzolana cement blends. Well graded aggregates conforming to BS882:1992 limits with maximum size of $20 \mathrm{~mm}$ were used. The coarse aggregates used consisted of crushed granite of $19 \mathrm{~mm}$ maximum size. River sand was used as fine aggregates which were in accordance with the grading requirement of BS 882 [17]. Table 3 shows the grading characteristics of the coarse and fine aggregates.

Table 1. Physical and Geotechnical properties of Type I and Type II clays

\begin{tabular}{lll}
\hline \multirow{2}{*}{ Property } & \multicolumn{2}{l}{ Clay deposits } \\
\cline { 2 - 3 } & Type I & Type II \\
\hline Colour & Reddish brown & Grey \\
Specific Gravity & 2.58 & 2.60 \\
Moisture Content $(\%)$ & 23.90 & 16.43 \\
Plastic Limit $(\%)$ & 42.80 & 17.60 \\
Liquid Limit $(\%)$ & 75.00 & 47.00 \\
Plasticity Index $(\%)$ & 37.20 & 29.40 \\
Clay Content $(<0.002 \mathrm{~mm})(\%)$ & 36 & 28 \\
Silt Content $(0.002-0.06 \mathrm{~mm})(\%)$ & 35 & 48 \\
Sand Content $(0.06-2.0 \mathrm{~mm})(\%)$ & 29 & 24 \\
Portland Cement & & \\
Colour & Grey & \\
Specific Gravity & 3.15 & \\
Blaine Fineness $\left(\mathrm{m}^{2} / \mathrm{kg}\right)$ & 338 & \\
\hline
\end{tabular}

Table 2. Chemical Composition of Type I and II clay Pozzolanas and Portland cement

\begin{tabular}{lllll}
\hline \multirow{2}{*}{ Oxides } & Type I & Type II & Portland & ASTM: C618-08 \\
\cline { 2 - 3 } & Pozzolana & Pozzolana & \multirow{2}{*}{ Cement } & CLASS N \\
\cline { 2 - 4 } & $(\boldsymbol{\%})$ & $(\boldsymbol{\%})$ & & \\
\hline $\mathrm{SiO}_{2}$ & 62.03 & 62.34 & 19.70 & $\left(\mathrm{SiO}_{2}+\mathrm{Al}_{2} \mathrm{O}_{3+} \mathrm{Fe}_{2} \mathrm{O}_{3}\right)$ \\
$\mathrm{Al}_{2} \mathrm{O}_{3}$ & 14.66 & 18.36 & 5.00 & $\geq 70 \%$ \\
$\mathrm{Fe}_{2} \mathrm{O}_{3}$ & 4.98 & 3.98 & 3.16 & \\
$\mathrm{CaO}$ & 0.21 & 0.25 & 63.03 & $(\mathrm{CaO}+\mathrm{MgO})$ \\
$\mathrm{MgO}$ & 1.75 & 1.40 & 1.75 & $\leq 5 \%$ \\
$\mathrm{SO}_{3}$ & 0.16 & 0.19 & 2.80 & \\
$\mathrm{NaO}_{2}$ & 2.30 & 1.82 & - & \\
$\mathrm{K}_{2} \mathrm{O}$ & 1.08 & 1.25 & 2.02 & Others \\
$\mathrm{TiO}_{2}$ & 1.04 & 1.35 & - & \\
$\mathrm{P}_{2} \mathrm{O}_{5}$ & 0.18 & 0.10 & - & \\
$\mathrm{MnO}$ & 0.10 & 0.05 & - & \\
$\mathrm{L} . \mathrm{O} . \mathrm{I}$ & 9.00 & 7.00 & 2.58 & $10 \%$ Maximum \\
\hline
\end{tabular}

Table 3. Grading of aggregate

\begin{tabular}{|c|c|c|c|c|}
\hline \multirow{3}{*}{ BS Test sieve (mm) } & \multicolumn{4}{|c|}{ Cumulative percentage passing } \\
\hline & \multirow{2}{*}{ Coarse Aggregates } & \multirow{2}{*}{$\begin{array}{l}\text { BS 882:1992 limits } \\
\text { comparison Table } 3 \text { : Col. } 2\end{array}$} & \multirow{2}{*}{ Fine Aggregates } & \multirow{2}{*}{$\begin{array}{l}\text { BS 882:1992 limits } \\
\text { comparison Table } 4: \text { F }\end{array}$} \\
\hline & & & & \\
\hline 37.50 & 100 & 100 & & \\
\hline 20.00 & 99 & $90-100$ & & \\
\hline 14.00 & 75 & $40-80$ & & \\
\hline 10.00 & 28 & $30-60$ & & \\
\hline 5.00 & 6 & $0-10$ & 100 & 100 \\
\hline 2.36 & & & 99 & $80-100$ \\
\hline 1.18 & & & 85 & $70-100$ \\
\hline 0.60 & & & 63 & $55-100$ \\
\hline 0.42 & & & 47 & - \\
\hline 0.30 & & & 34 & $0-70$ \\
\hline 0.15 & & & 12 & $0-15$ \\
\hline
\end{tabular}




\subsection{Experimental Program}

\subsubsection{Mix Proportions and Specimen Preparation}

The American Concrete Institute method (ACI) was adopted for the mix proportions and was designed to give nominal concrete strengths of 25,30 and $40 \mathrm{~N} / \mathrm{mm}^{2}$. Ordinary Portland cement was partially replaced with0\%, 5\%, 10\%, $15 \%, 20 \%$ and $25 \%$ of Type I clay pozzolana and $0 \%, 5 \%$, $10 \%, 15 \%, 20 \%, 25 \%$ and $30 \%$ of Type II clay pozzolana. Table 4 presents the mix proportions of the designed pozzolana concrete. The standard consistency and setting times of the cement and pozzolana paste mixtures were determined with the Vicat apparatus in accordance with BS EN 197-1[18]. The workability of the fresh formulated concrete mixes was measured using the slump mould. The density of the concrete was also determined after 24 hours.

$100 \mathrm{~mm}$ concrete cubes and concrete prisms measuring 100 $\mathrm{x} 100 \times 500 \mathrm{~mm}$ were used to determine the compressive and tensile strengths respectively. The concrete specimens were cured continually under portable water for $7,28,56$, or 90 days prior to testing at room temperature.

Table 4. Mix Proportion of Designed Pozzolana-cement Concrete

\begin{tabular}{|c|c|c|c|c|c|c|c|c|c|c|c|c|c|c|c|c|c|c|c|c|c|}
\hline Mixture NO. & 1 & & & & & & & 2 & & & & & & & 3 & & & & & & \\
\hline Class of Concrete $\left(\mathrm{N} / \mathrm{mm}^{2}\right)$ & 25 & & & & & & & 30 & & & & & & & 40 & & & & & & \\
\hline Percentage Replacement & 0 & 5 & 10 & 15 & 20 & 25 & 30 & 0 & 5 & 10 & 15 & 20 & 25 & 30 & 0 & 5 & 10 & 15 & 20 & 25 & 30 \\
\hline $\begin{array}{l}\text { Ordinary Portland Cement } \\
\left(\mathrm{kg} / \mathrm{m}^{3}\right)\end{array}$ & 373 & 354 & 336 & 317 & 298 & 280 & 261 & 410 & 390 & 369 & 349 & 328 & 308 & 287 & 456 & 433 & 410 & 388 & 365 & 342 & 319 \\
\hline Clay Pozzolana $\left(\mathrm{kg} / \mathrm{m}^{3}\right)$ & - & 19 & 37 & 56 & 75 & 93 & 112 & - & 67 & 41 & 62 & 82 & 149 & 123 & - & 23 & 46 & 68 & 91 & 114 & 137 \\
\hline $\mathrm{W} / \mathrm{C}$ & 0.55 & & & & & & & 0.50 & & & & & & & 0.45 & & & & & & \\
\hline Water $\left(\mathrm{kg} / \mathrm{m}^{3}\right)$ & 205 & & & & & & & 205 & & & & & & & 205 & & & & & & \\
\hline Fine Aggregates $\left(\mathrm{kg} / \mathrm{m}^{3}\right)$ & 746 & & & & & & & 713 & & & & & & & 684 & & & & & & \\
\hline Coarse Aggregates $\left(\mathrm{kg} / \mathrm{m}^{3}\right)$ & 1026 & & & & & & & 1025 & & & & & & & 1026 & & & & & & \\
\hline
\end{tabular}

\subsubsection{Testing of Concrete Cubes and Prisms}

The concrete prisms cured under water were removed at the testing time. The specimens attain a saturated dry state before crushing. The concrete cubes were tested to failure in a compressive machine at different ages to determine compressive strength. Flexural test was on the prisms to determine the tensile strength of the various mixes in accordance with BSEN12390-5 [26]. An average of three concrete specimens was tested to represent the values of the compressive and flexural strengths.

\section{Results and Discussions}

\subsection{Standard Consistency and Setting Time}

The effect of clay pozzolana on standard consistency and setting times of Portland cement is as presented in Tables 5. The table shows that the amount of water required for the desired consistency for Type I and Type II pastes increased ranging from $3.7 \%-29.6 \%$ and $3.7 \%-37 \%$ respectively as compared to the control paste. The reason could be due to the lower specific gravity of clay pozzolana compared to the ordinary Portland cement, hence the requirement of larger volumes of clay pozzolana to replace the same mass of ordinary Portland cement. It was observed from the table that relatively, same weight replacement values between $5 \%$ and $25 \%$ of Type I clay pozzolana required more water than its Type II pozzolana counterpart in the cement paste. This shows that Type I pozzolana may have a relatively high pore structure than Type II sample.

From Table5, the initial and final setting times of both types of clay pozzolana cements (Type I and Type II clay pozzolana samples) were greater than the control paste. Both initial and final setting times of the pozzolanic paste increased with the percentages of clay pozzolana. The reason for this trend was that the clay pozzolana reduced the cement content which serves as the stiffening agent. This consequently reduced the rate of hydration and led to slow stiffening and hardening of the paste thereby prolonging the hydration process.

Table 5. Consistency and Setting times of Clay Pozzolanic Cement

\begin{tabular}{lllllll}
\hline \multirow{2}{*}{ Code } & $\mathbf{P}$ & $\mathbf{K}$ & $\mathbf{W} /$ & \multicolumn{2}{l}{ Consistency } & \multicolumn{2}{l}{ Setting Time (min) } \\
\cline { 2 - 7 } & $(\boldsymbol{\%})$ & $(\boldsymbol{\%})$ & $(\mathbf{P}+\mathbf{K})$ & $(\boldsymbol{\%})$ & Initial & Final \\
\hline C0 & 100 & 0 & 0.27 & 26.8 & 90 & 196 \\
PT1 & 95 & 5 & 0.26 & 26.4 & 92 & 210 \\
PT2 & 90 & 10 & 0.28 & 28.0 & 95 & 210 \\
PT3 & 85 & 15 & 0.30 & 30.2 & 102 & 218 \\
PT4 & 80 & 20 & 0.32 & 32.0 & 114 & 223 \\
PT5 & 75 & 25 & 0.35 & 35.4 & 138 & 233 \\
PT6 & 70 & 30 & 0.37 & 37.0 & 157 & 242 \\
PM1 & 95 & 5 & 0.28 & 28.0 & 108 & 205 \\
PM2 & 90 & 10 & 0.30 & 30.0 & 125 & 210 \\
PM3 & 85 & 15 & 0.31 & 31.0 & 142 & 213 \\
PM4 & 80 & 20 & 0.33 & 33.0 & 163 & 225 \\
PM5 & 75 & 25 & 0.35 & 35.2 & 178 & 230 \\
\hline
\end{tabular}

Note: CO-Control, PM-Portland cement and Type I, PT-Portland cement and Type II pozzolana pozzolana, P-Portland cement, K-Pozzolana, W-Water.

\subsection{Workability and Densities of Fresh Concrete}

The workability of the fresh concrete and their densities 
determined after 24hours are presented in Table 6. The control slumps were $65 \mathrm{~mm}, 55 \mathrm{~mm}$ and $42 \mathrm{~mm}$ for concrete class 25, 30 and $40 \mathrm{MPa}$ respectively. The table shows that slump for Type II clay pozzolana concrete of classes $25 \mathrm{~N} / \mathrm{mm}^{2}, 30 \mathrm{~N} / \mathrm{mm}^{2}$ and $40 \mathrm{~N} / \mathrm{mm}^{2}$ ranged from $54 \mathrm{~mm}-$ $30 \mathrm{~mm}, 47 \mathrm{~mm}-20 \mathrm{~mm}, 35 \mathrm{~mm}-12 \mathrm{~mm}$ respectively whereas that for Type I concretes were from $50 \mathrm{~mm}-28 \mathrm{~mm}, 40 \mathrm{~mm}-$ $20 \mathrm{~mm}$ and $30 \mathrm{~mm}-10 \mathrm{~mm}$ respectively. Concretes that contained any of the clay pozzolana either Type I or Type II had a lower slump than the control. The control mixes had better workabilities than the pozzolanic cement concretes generally. The table shows a progressive decrease in slump as the pozzolanic content increased. This could be attributed to the fact that the high surface area of the clay pozzolana increased the water demand for the cement-pozzolana system and therefore for a given water-cement ratio and cement content, the workability of the mix was reduced.

In addition, it was observed that concretes prepared with pozzolana did not show any tendency to bleed and segregate as a result of high cementitious contents in terms of volume owing to the lower specific gravity of clay pozzolanas.

The unit weight after 24hours which is shown in Table 6 generally recorded a decreasing trend for both Type I and II pozzolana concretes for all the concrete classes (24MPa, $30 \mathrm{MPa}$ and $40 \mathrm{MPa}$ ) as compared to the control concrete mix. The density results also indicated a gradual fall with increasing pozzolana content. This trend was expected because the pozzolana cement concrete displayed lower unit weight due to the lower specific gravity of clay particles (2.58 for Type I clay and 2.60 for Type II clay), as compared to that of the ordinary Portland cement which was 3.15.

Table 6. Slumps and Density of various mixes for specified Characteristic strengths

\begin{tabular}{lllllllll}
\hline \multirow{2}{*}{ No. } & \multirow{2}{*}{ Code } & \multicolumn{1}{l}{ K } & \multicolumn{3}{c}{ Slump $(\mathbf{m m})$} & \multicolumn{3}{c}{ Density $\left(\mathbf{k g} / \mathbf{m}^{\mathbf{3}}\right)$} \\
\cline { 3 - 8 } & & $\mathbf{( \% )}$ & $\mathbf{2 5}$ & $\mathbf{3 0}$ & $\mathbf{4 0}$ & $\mathbf{2 5}$ & $\mathbf{3 0}$ & $\mathbf{4 0}$ \\
\hline 1 & C0 & 0 & 65 & 55 & 42 & 2505 & 2550 & 2620 \\
2 & PT1 & 5 & 54 & 47 & 35 & 2492 & 2520 & 2590 \\
3 & PT2 & 10 & 48 & 40 & 28 & 2475 & 2515 & 2570 \\
4 & PT3 & 15 & 42 & 35 & 25 & 2450 & 2505 & 2555 \\
5 & PT4 & 20 & 38 & 30 & 21 & 2400 & 2490 & 2510 \\
6 & PT5 & 25 & 35 & 22 & 18 & 2380 & 2482 & 2500 \\
7 & PT6 & 30 & 30 & 20 & 12 & 2370 & 2475 & 2495 \\
8 & PM1 & 5 & 50 & 40 & 30 & 2498 & 2500 & 2595 \\
9 & PM2 & 10 & 45 & 36 & 25 & 2485 & 2495 & 2580 \\
10 & PM3 & 15 & 40 & 30 & 21 & 2470 & 2475 & 2570 \\
11 & PM4 & 20 & 35 & 25 & 15 & 2455 & 2470 & 2530 \\
12 & PM5 & 25 & 28 & 20 & 10 & 2448 & 2460 & 2505 \\
\hline
\end{tabular}

Note: CO-Control, PM-Portland cement and Type I, PT-Portland cement and Type II pozzolana pozzolana, P-Portland cement, K-Pozzolana, W-Water.

\subsection{Properties of Hardened Concrete}

\subsubsection{Compressive Strength}

Compressive strength results of Type I and II pozzolana and cement concretes are shown in Figures 1 and 2. The figures show that the concrete strength increased with curing time for both the controlled concrete and Portland pozzolana concretes. The improvement of Portland pozzolana concretes was more pronounced after 28days of moist curing. It was noticed that the compressive strength of both pozzolanic concretes (Type I and Type II) decreased with increasing substitution of pozzolana at ages 7 days and 28days and virtually all were less than the reference mixes except strength class $30 \mathrm{MPa}$ of Tanoso pozzolana of which up to $15 \%$ replacement at 28 days was greater than the control. The results showed that for $10 \%$ replacement at 28 day curing, the strengths obtained for Type II and Type I specimens were less than the reference specimen by an average of $3 \%$. However at 56days and 90days curing age, the compressive strength of pozzolana incorporated concrete specimens improved. They exceeded the reference mixes by $9 \%$ at 56 days and $14 \%$ at 90days on the average. Similar trends were observed for $15 \%$ substitution. The decrease in strength for all the grades was $4 \%$ at age 28 days. The results further showed an increase in strength of pozzolana blended specimens over the plain specimens at ages 56days and 90days. The increases were $6 \%$ and $11 \%$ for ages 56days and 90days respectively for both samples on the various grades of concrete. On $20 \%$ cement replacement, the compressive strengths averaged $94 \%$ of the referenced strength at 28days. At age 56days, the Type I clay pozzolana specimens was similar to the control while the Type II specimens had about $103 \%$ of the compressive strength of the control for all the grades. An increase in strength was also observed at 90days. The compressive strength after 90 days averaged $111 \%$ of the control. The compressive strength dropped sharply beyond $20 \%$ partial replacement for both samples. It was observed that beyond $20 \%$ for both samples, the compressive strength dropped sharply for all the curing ages. This implies that partial substitution of Type II and Type I clay pozzolana beyond $20 \%$ may not be beneficial to the chosen mix design concrete in terms of compressive strength.

These results indicate that clay pozzolana Portland cement concrete gains strength slowly at early curing age. This affirms existing knowledge of low early strength which has been a major setback in the use of pozzolana cement for mortar and concrete works. A longer curing period is therefore needed to achieve its positive effects. The results are in agreement with the compressive strength results presented by Khatib and Hibbert [20] and Sata et al. [21]. These results further indicate that $20 \%$ of clay pozzolanas were sufficient to react with the liberated lime (calcium hydroxide) generated from cement paste to form stable compounds possessing cementitious properties leading to increased strength. The drop in the gain of compressive strength of clay pozzolana in Portland cement leads to the conclusion that, the $20 \%$ replacement for Type II and Type I pozzolanas was the optimum. Beyond this any addition of pozzolana acts as mere filler in the concrete matrix due to the depleted source of liberated calcium hydroxide $\left(\mathrm{CaOH}_{2}\right)$. 

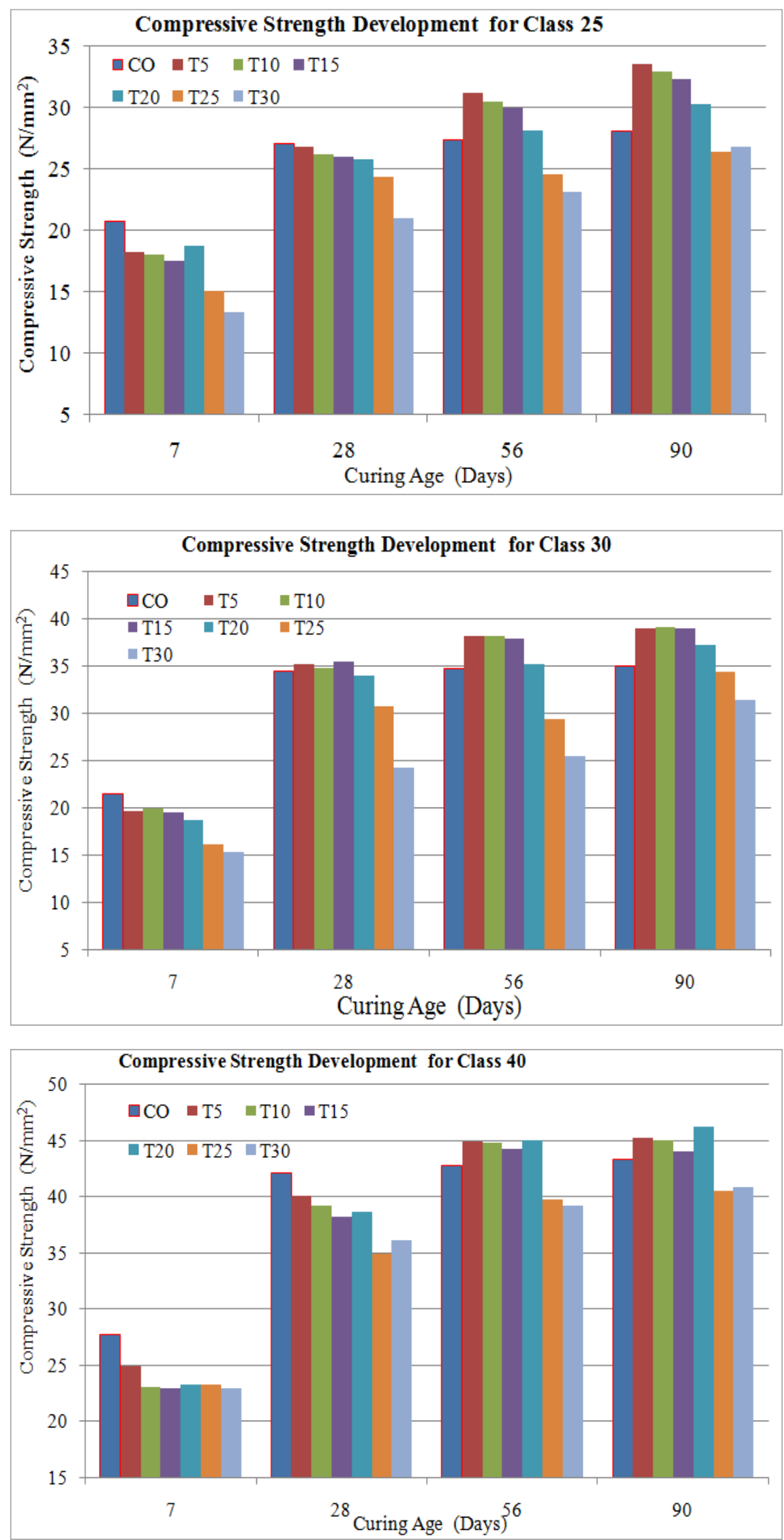

Fig. 1. The relationship between compressive strength and curing time of Type II clay pozzolana blended mixes. 

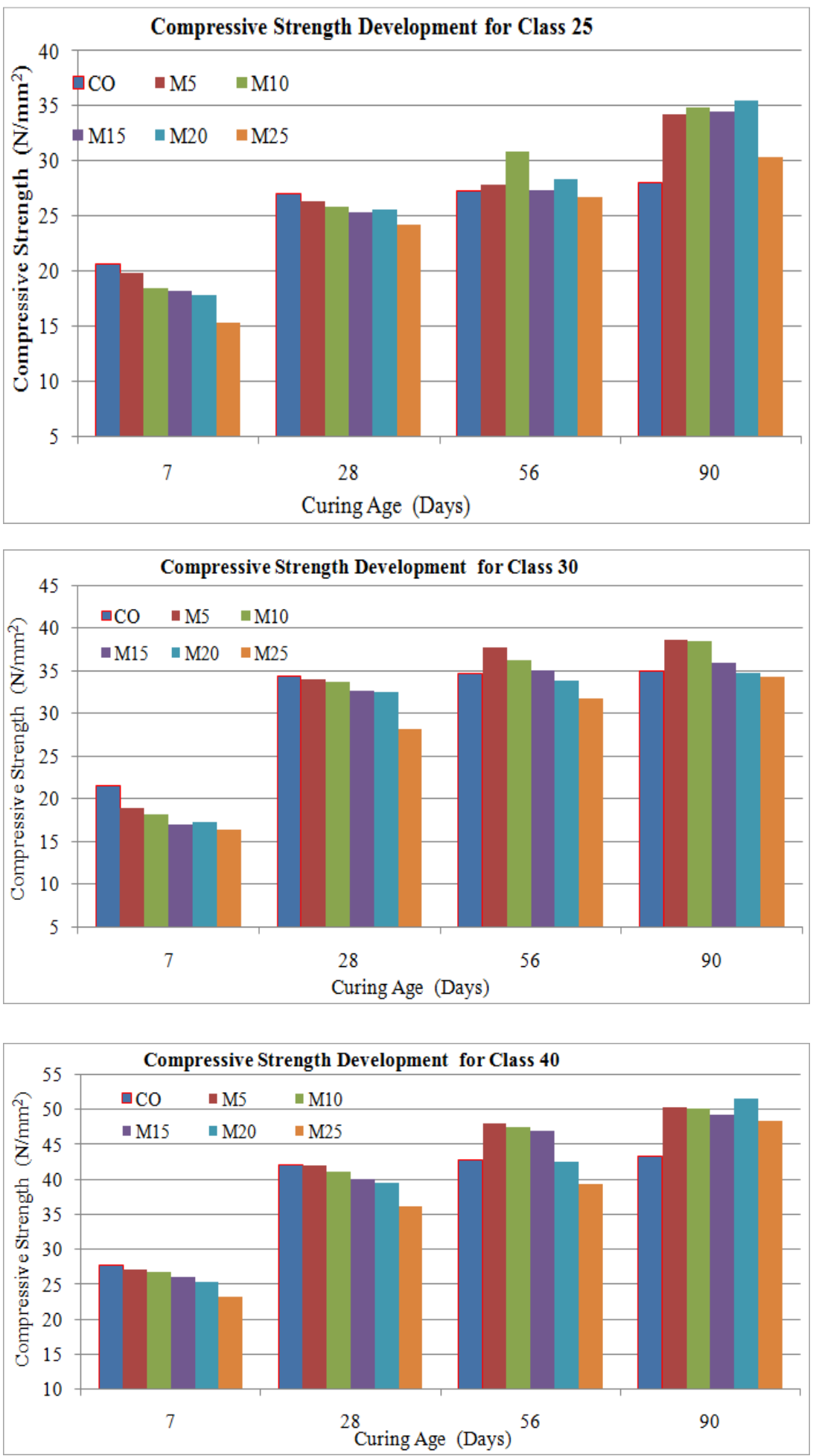

Fig. 2. The relationship between compressive strength and curing time of Type I clay pozzolana blended mixes.

\subsubsection{Tensile Strength}

Figures 3 and 4 present the flexural strength results of Type II and I cement and pozzolana concrete mixes. Similarly, the flexural tensile strength or modulus of rupture of clay pozzolana concrete increased as compressive strength increased with curing age for all grades of concrete. On the other hand it decreased with the increasing substitution of clay pozzolana. From Figures 3 and 4, the Portland pozzolana concrete mixes at age 7 days, exhibited lower modulus of rupture compared with the conventional Portland cement mixtures except grade 40 where 5-20\% of Type II and 5-15\% of Type I clay pozzolana contents exceeded the control. The situation was different at ages 28, 56 and 90 days for partial replacement between $10 \%$ and $20 \%$ for both samples where higher flexural strengths were recorded for the blended specimens. At age 28days, the flexural strengths of Type II and 
Type I pozzolana incorporated specimens averaged $112 \%$ and $105 \%$ of the control specimens respectively. The tensile strengths of Type II specimens at ages 56days and 90days were $109 \%$ and $110 \%$ of the control mixes respectively. For Type I specimens the strengths were $102 \%$ and $117 \%$ greater than the control at ages 56days and 90days respectively.

It was observed from the tests that fracture occurred within the central one-third span of all the prisms.

The relationship between the flexural strength $\left(f_{t c}\right)$ and compressive strength $\left(\mathrm{f}_{\mathrm{cu}}\right)$ is presented in Table 7.For the control specimens the ratio $\mathrm{f}_{\mathrm{tc}} / \mathrm{f}_{\mathrm{cu}}$ ranged from 9 to $14 \%$. For the Type II and Type I pozzolana incorporated specimens the ratio, $\mathrm{f}_{\mathrm{tc}} / \mathrm{f}_{\mathrm{cu}}$ varied from 7 to $15 \%$, and 8 to $14 \%$ respectively. As shown in Table 7 , the ratio between the tensile strength $\left(f_{t c}\right)$ and the compressive strength $\left(f_{c u}\right)$ concrete at 28 days indicates that the higher the compressive strength of concrete the lower the ratio which is consistent with the data published by Shannag [22].

Portland pozzolana concretes exhibited relatively higher values of tensile strength which render them better for unreinforced structures such as dams under earthquake conditions, highway and airfield pavements [30].
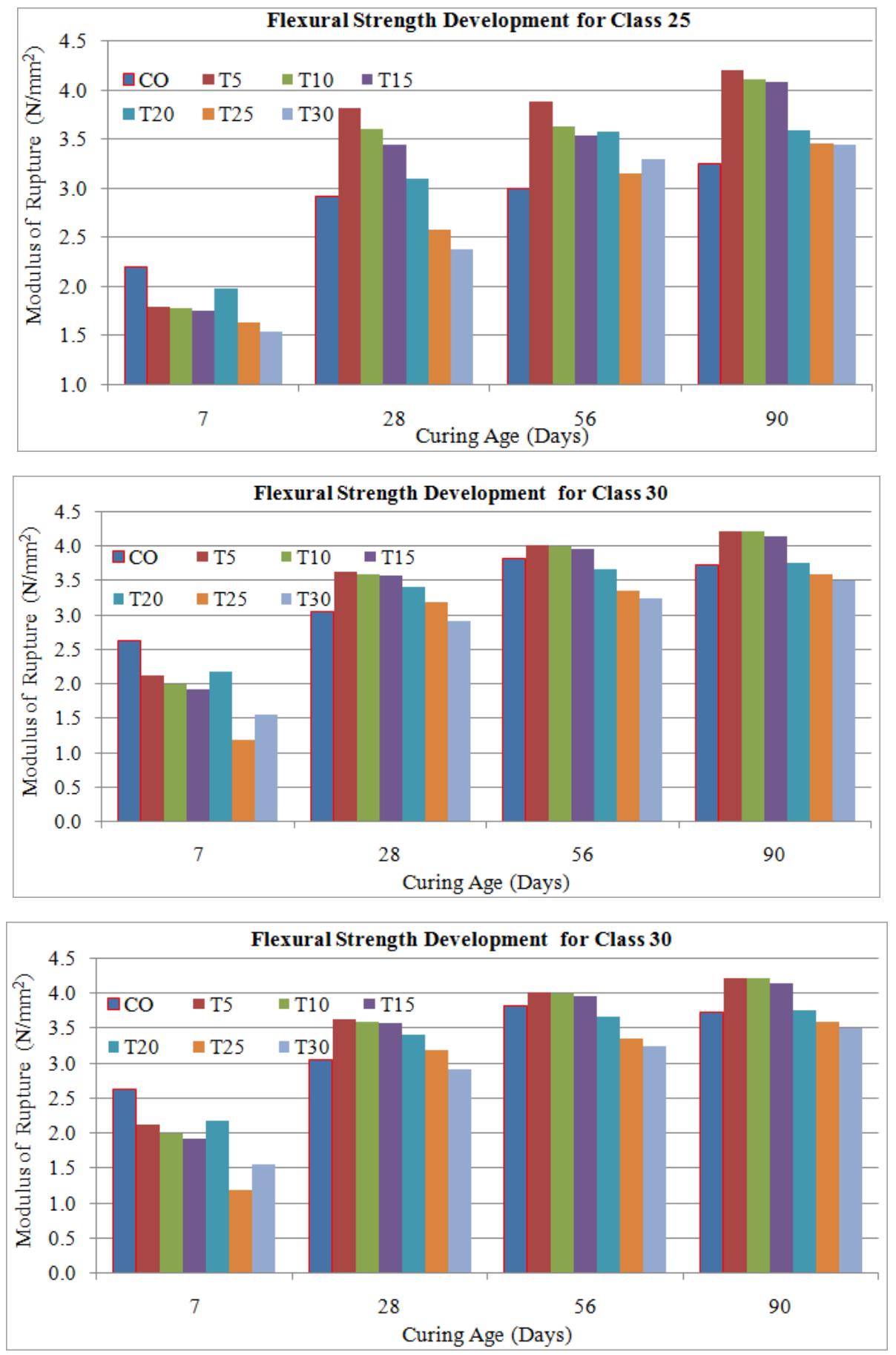

Fig. 3. The relationship between flexural strength and curing time of Type II clay pozzolana blended mixes. 

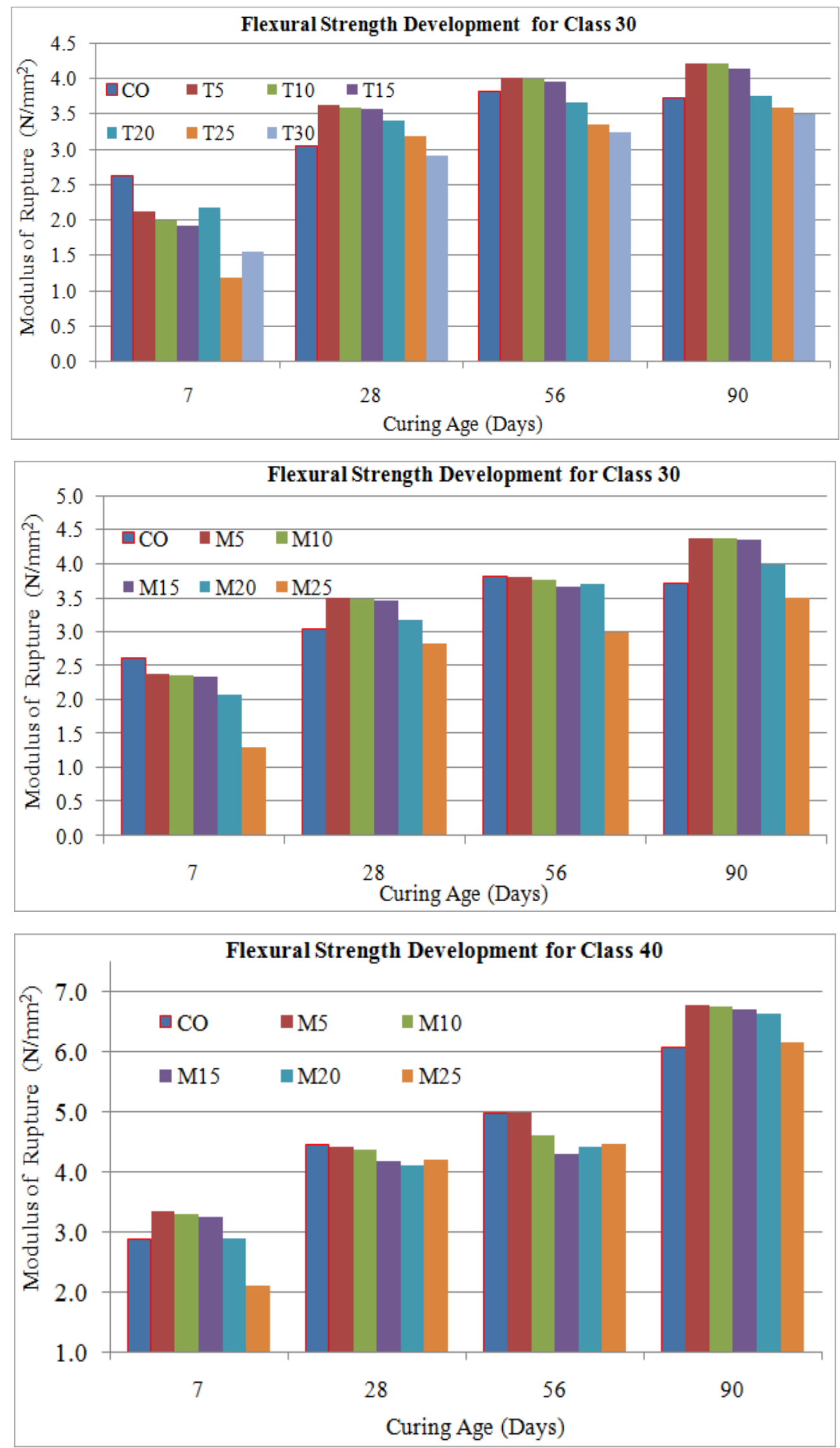

Fig. 4. The relationship between flexural strength and curing time of Type I clay pozzolana blended mixes 
Table 7. Relationship between Tensile and Compressive strengths

\begin{tabular}{|c|c|c|c|c|c|c|c|c|c|c|c|c|c|}
\hline \multirow{4}{*}{ No. } & \multirow{4}{*}{ Code } & \multicolumn{12}{|l|}{$\mathbf{f}_{\mathrm{tc}} / \mathbf{f}_{\mathrm{cu}}$} \\
\hline & & \multicolumn{4}{|l|}{25} & \multicolumn{4}{|l|}{30} & \multicolumn{4}{|l|}{40} \\
\hline & & 7 & 28 & 56 & 90 & 7 & 28 & 56 & 90 & 7 & 28 & 56 & 90 \\
\hline & & days & days & days & days & days & days & days & days & days & days & days & days \\
\hline 1 & $\mathrm{CO}$ & 0.11 & 0.11 & 0.11 & 0.12 & 0.12 & 0.09 & 0.11 & 0.11 & 0.10 & 0.11 & 0.12 & 0.14 \\
\hline 2 & T5 & 0.10 & 0.14 & 0.12 & 0.13 & 0.11 & 0.10 & 0.10 & 0.11 & 0.13 & 0.13 & 0.12 & 0.14 \\
\hline 3 & $\mathrm{~T} 10$ & 0.10 & 0.14 & 0.12 & 0.12 & 0.10 & 0.10 & 0.10 & 0.11 & 0.14 & 0.13 & 0.12 & 0.14 \\
\hline 5 & $\mathrm{~T} 20$ & 0.11 & 0.12 & 0.13 & 0.12 & 0.12 & 0.10 & 0.10 & 0.10 & 0.14 & 0.10 & 0.12 & 0.14 \\
\hline 6 & $\mathrm{~T} 25$ & 0.11 & 0.11 & 0.13 & 0.13 & 0.07 & 0.10 & 0.11 & 0.10 & 0.11 & 0.11 & 0.12 & 0.15 \\
\hline 7 & T30 & 0.12 & 0.11 & 0.14 & 0.13 & 0.10 & 0.12 & 0.13 & 0.11 & 0.11 & 0.10 & 0.13 & 0.14 \\
\hline 8 & M5 & 0.11 & 0.12 & 0.13 & 0.12 & 0.13 & 0.10 & 0.10 & 0.11 & 0.12 & 0.11 & 0.10 & 0.13 \\
\hline 9 & M10 & 0.11 & 0.12 & 0.12 & 0.11 & 0.13 & 0.10 & 0.10 & 0.11 & 0.12 & 0.11 & 0.10 & 0.13 \\
\hline 10 & M15 & 0.12 & 0.12 & 0.13 & 0.12 & 0.14 & 0.11 & 0.10 & 0.12 & 0.12 & 0.10 & 0.09 & 0.14 \\
\hline 12 & M25 & 0.12 & 0.09 & 0.11 & 0.12 & 0.08 & 0.10 & 0.09 & 0.10 & 0.09 & 0.12 & 0.11 & 0.13 \\
\hline
\end{tabular}

C: Control, T: Tanoso pozzolana, M: Mankranso pozzolana.

\section{Conclusions}

Based on the results obtained from the investigations, the following conclusions are drawn:

1) Chemically, the pozzolana samples are siliceous. The main oxide $\left(\mathrm{SiO}_{2}+\mathrm{Al}_{2} \mathrm{O}_{3}+\mathrm{Fe}_{2} \mathrm{O}_{3}\right)$ content exceeded the minimum of $70 \%$ set by ASTM: C618standard specification for calcined natural pozzolana for use in concrete.

2) The addition of calcined clay to Portland cement increases the normal consistency of the blended Portland cement mixtures.

3) The concrete slump as well as their respective densities decreased as the clay pozzolana content increased.

4) The addition of clay pozzolana retarded both initial and final setting times. This is of particular importance in ready mixed concrete as there is extra time to ensure fresh concrete delivery to site.

5) The compressive strengths of blended pozzolana-cement concrete were lower than that of the control plain concrete at early curing age of 7 days. At 28 days, the shortfall in compressive strength on the grades of concrete averaged $6 \%$ for Tanoso (Type II) and Mankranso (Type I) samples on $20 \%$ replacement.

6) Beyond 28days, the compressive strength improved significantly. Partial substitutions of up to $20 \%$ for both samples surpassed the 28days strength of plain concrete, varying from $1 \%$ to $15 \%$ at 56 days and $5 \%$ to $31 \%$ at 90days of curing.

7) The flexural strength improvement was significant. At most $15 \%$ blended concretes for both samples surpassed their respective grades tensile strengths at age 28 days. Incorporation of up to $30 \%$ of Tanoso samples equaled or exceeded the 28days strength at 56days testing. Similarly, Portland cement-mankranso pozzolana concretes exhibited same for replacement up to $25 \%$.

8) Concretes prepared with pozzolana did not show any tendencies of bleeding and segregation.

\section{References}

[1] Plenge WH. Roadmap 2030,The U.S Concrete Industry Technology Roadmap, Concrete Research \& Education Foundation, U.S.A; 2002

[2] Mehta PK, \&Monteiro PJM., Concrete structure, properties and materials, New Jersey Prentice Hall, U.S.A; 1993

[3] Mehta PK. High-Performance, high-volume fly ash concrete for sustainable development, International workshop on sustainable development and concrete technology; 2006

[4] Ki-Chang L, Jai-Hyuk H, Soon-Ki K. Red clay composites reinforced with polymeric binders, Construction and Building Materials2008: 22: 2292-2298

[5] Alam MJB, Awal ASMA, Hasan A, Banik BK, Alam S, Hasan MM. Possible use of Fly ash generated from Barapukeria power plant for sustainability, ARPN Journal of Engineering and Applies Sciences 2006; 1: 60-63

[6] Vu DD, Stroevan P, Bui VB. Strength and Durability aspect of Calcined kaolin-blended Portland cement Mortars and Concrete, Cement and Concrete Research 2001; 27(1): 471-478

[7] Osborne GJ. Durability of Portland blast-furnace slag cement concrete, Cement and Concrete Composites 1999; 21: 11-15

[8] Fragoulis D, Stamatakis MG, Papageorgiou D, Chaniotakis E. The physical and mechanical properties of composite cements manufactured with calcareous and clayey Greek diatomite mixtures, Cement and Concrete Composites 2005; 27: 205-209.

[9] Al-Dulaijan, SU. Sulfate resistance of plain and blended cements exposed to magnesium sulfate solutions, Construction and Building Materials 2007; 21:1792- 1802

[10] Shehata HM, Adhikari G, Radomski S. Long-Term durability of blended cement against sulphate attack, ACI Materials Journal 2008; 105-M67; 594-602

[11] Thomas DAM., Scott A, Bremner T, Bilodeau T, Day D. Performance of Slag Concrete in Marine Environment, ACI Materials Journal 2008;105-M71: 628-634 
[12] Sumrerng R, Prinya C. Utilization of bagasse ash in highstrength concrete, Materials and Design 2012; 34: 45-50

[13] Tironi A, Trezza, MA, Scian AN., Irassar EF. Kaolinitic calcined clays: Factors affecting its performance as pozzolans, Construction and Building Materials 2012; 28: 276-281

[14] Sabir BB, Wild S, Bai J. Metakaolin and Calcined Clay as pozzolans for concrete: a review. Cement and Concrete Composites 2001; 23: 441-454.

[15] Atiemo E. Production of pozzolana from some local claysProspects for application in housing construction, Journal of Building and Road Research 2005; 9 (1\&2): 34-37

[16] Atiemo E. Evaluation of Clay Pozzolana as a partial replacement of cement for Shelter construction, MPhil unpublished Thesis 1998, KNUST, Kumasi, Ghana

[17] British Standards Institution. Specification for Aggregates from Natural Sources for Concrete, BS 882: London; 1992

[18] European committee for standardization Cement: Composition, Specification and conformity criteria for common Cements, BSEN 197-1; 2000
[19] European committee for standardization Testing hardened concrete: Flexural strength of test specimens, BSEN 12390-5; 2000

[20] Khatib JM, Hibbert JJ. Selected engineering properties of concrete incorporating slag and metakaolin, Construction and Building Materials 2005; 19: 460-472

[21] Sata V, Jaturapitakkul C, Kiattikomol K. Influence of pozzolan from various by-product materials on mechanical properties of high-strength concrete, Construction and Building Materials 2007; 21: 1589 - 1598

[22] Shannag MJ. High strength concrete containing natural pozzolan and silica fume, Cement and Concrete Composites2000; 22: 399 - 406

[23] Neville AM. Properties of Concrete, Fourth Edition, Pitman \& Sons Ltd; 1995. 